OPEN ACCESS

Edited by:

Ying-Jun Chang,

Peking University People's Hospital,

China

Reviewed by:

Yongxia Wu,

Medical University of South Carolina,

United States

Andy Peng Xiang,

Sun Yat-sen University, China

${ }^{*}$ Correspondence:

Shijie Yang

xyzysj102@163.com

Xi Zhang

zhangxxi@sina.com

Specialty section:

This article was submitted to Alloimmunity and Transplantation,

a section of the journal

Frontiers in Immunology

Received: 26 August 2021 Accepted: 08 November 2021

Published: 24 November 2021

Citation:

Wang $W$, Hong $T$, Wang $X$, Wang $R$, Du Y, Gao Q, Yang $S$ and Zhang $X$ (2021) Newly Found Peacekeeper: Potential of CD8+ Tregs for GraftVersus-Host Disease.

Front. Immunol. 12:764786. doi: 10.3389/fimmu.2021.764786

\section{Newly Found Peacekeeper: Potential of CD8+ Tregs for Graft-Versus- Host Disease}

\author{
Weihao Wang ${ }^{1,2}$, Tao Hong ${ }^{1,2}$, Xiaoqi Wang ${ }^{1,2}$, Rui Wang ${ }^{1,2}$, Yuxuan $\mathrm{Du}^{1,2,3}$, \\ Qiangguo $\mathrm{Gao}^{4}$, Shijie Yang ${ }^{1,2 *}$ and Xi Zhang ${ }^{1,2 *}$
}

\begin{abstract}
'Medical Center of Hematology, Xinqiao Hospital, Army Medical University, Chongqing, China, ${ }^{2}$ State Key Laboratory of Trauma, Burns and Combined Injury, Army Medical University, Chongqing, China, ${ }^{3}$ Department of Laboratory Medicine, the Affiliated Hospital of Zunyi Medical University, Zunyi, China, ${ }^{4}$ Department of Cell Biology, College of Basic Medicine, Army Medical University, Chongqing, China
\end{abstract}

Allogeneic hematopoietic stem cell transplantation (allo-HSCT) remains the most effective and potentially curative treatment for a variety of hematologic malignancies. However, graft-versus-host disease (GVHD) is a major obstacle that limits wide application of alloHSCT, despite the development of prophylactic strategies. Owing to experimental and clinical advances in the field, GVHD is characterized by disruption of the balance between effector and regulatory immune cells, resulting in higher inflammatory cytokine levels. A reduction in regulatory $T$ cells (Tregs) has been associated with limiting recalibration of inflammatory overaction and maintaining immune tolerance. Moreover, accumulating evidence suggests that immunoregulation may be useful for preventing GVHD. As opposed to $\mathrm{CD}^{+}$Tregs, the $\mathrm{CD} 8^{+}$Tregs population, which constitutes an important proportion of all Tregs, efficiently attenuates GVHD while sparing graftversus-leukemic (GVL) effects. CD8 ${ }^{+}$Tregs may provide another form of cellular therapy for preventing GVHD and preserving GVL effects, and understanding the underlying mechanisms that different from those of $\mathrm{CD} 4^{+}$Tregs is significant. In this review, we summarize preclinical experiments that have demonstrated the role of $\mathrm{CD} 8^{+}$Tregs during GVHD and attempted to obtain optimized CD8 ${ }^{+}$Tregs. Notably, although optimized CD8 ${ }^{+}$ Tregs have obvious advantages, more exploration is needed to determine how to apply them in the clinic.

Keywords: hematopoietic stem cell transplantation, graft-versus-host disease, CD8, CD4, regulatory T cells

\section{INTRODUCTION}

Allo-HSCT was established to treat patients with hematological malignancies. Rejection, GVHD and infections are major clinical complications after allo-HSCT and are associated with graft failure and transplant-related morbidity and mortality. These complications continue to impede successful transplantation and limit its curative effect. Thus, overcoming such complications is the main objective to improve allo-HSCT outcomes and to patient quality of life. Preventing GVHD with immunosuppressant may lead to side effects such as severe infection, hematologic 
malignancy relapse and multiorgan dysfunction, which are important factors in transplantation-related mortality. In addition, broad- and long-term immunosuppressive therapy for GVHD may subsequently dampen beneficial GVL responses, constituting an ongoing challenge.

Researchers have discovered several regulatory cell subsets that prevent the occurrence and development of GVHD, among which adoptive regulatory Tregs suppress the function of effector $\mathrm{T}$ cells (1) and play a crucial role in limiting immune response overaction, regulating immune homeostasis (2) and maintaining tolerance (3), improving the outcome of GVHD. In addition to $\mathrm{CD}^{+}$Tregs, which dominate regulatory cells in autoimmune diseases, $\mathrm{CD}^{+}$suppressor $\mathrm{T}$ cells are emerging as an important subset of regulatory $\mathrm{T}$ cells and have received much attention. Recently, more and more clinical data have verified the significant roles. Researchers have found a lower proportion of $\mathrm{CD}^{+}$Tregs in GVHD patients (4). Moreover, patients with autoimmune diseases like multiple sclerosis (5), type 1 diabetes (6), common variable immunodeficiency (7) have shown the same tendency of $\mathrm{CD}^{+}$Tregs. In addition, patients after HSCT with lupus remission have a greater number of $\mathrm{CD}^{+}$Tregs (8) and anti-CD20 treatment in multiple sclerosis is also associated with increased $\mathrm{CD}^{+}$Tregs (9), indicating that $\mathrm{CD} 8^{+}$Tregs could alleviate immune response. However, $\mathrm{CD}^{+}$Tregs do not always benefit to health, which showed higher proportions in chronic lymphocytic leukemia (10), multiple myeloma (11) and solid tumors like hepatocellular carcinoma, ovarian cancer and lung cancer (12-14). But alloreactive $\mathrm{CD}^{+}$Tregs are less stable than $\mathrm{CD}^{+}{ }^{+}$Tregs but efficiently attenuate GVHD while preserving the GVL effect. Although $\mathrm{CD} 8^{+}$Tregs were described before CD4 ${ }^{+}$ Tregs, their biology is less well understood due in part to their small numbers, thus rendering functional studies difficult.

In this review, we discuss the biology and development of $\mathrm{CD}^{+}$Tregs, their contribution to reducing GVHD while preserving GVL effects apart from $\mathrm{CD}^{+}{ }^{+}$Tregs as well as their heterogeneity, focusing on questions and future improvements through genetic technologies.

\section{REVIVAL OF CD8 ${ }^{+}$TREGS}

$\mathrm{CD}^{+}$Tregs were the first suppressive cells reported (15). Despite many studies, the exact definition of $\mathrm{CD} 8^{+}$Tregs remains unclear, and a lack of assessment has caused difficulty in marker discovery. Expression of the common and sensitive marker FOXP3 is lower in $\mathrm{CD}^{+}$Tregs than in $\mathrm{CD}^{+}$Tregs in both mouse and human studies. However, FOXP3 correlate with the activation and potential suppressive capacity of $\mathrm{CD} 8^{+}$Tregs (16). A study in 2018 involving $\mathrm{CD}^{+}$Tregs single-cell RNA sequencing highlighted some important transcription factors and membrane molecules related to immunosuppressive functions, including FOXP3, IKZF2 (IKAROS), TNFR2, IL2RA and IL2RB, in mice and humans (17). Recent data on $\mathrm{CD}^{+}$Tregs confirm that Bim and Mcl-1 expression contributes to immune regulation (18), though the regulatory ability of Tregs subsets differ. Studies have demonstrated that $\mathrm{CD} 4^{+}$Tregs function correlates with the repertoire of TCRs $(19,20)$, whereas $\mathrm{CD}^{+}$Tregs are largely related to the proapoptotic phenotype (18). $\mathrm{CD} 8^{+}$Tregs mainly interact with $\mathrm{CD} 8^{+} \mathrm{T}$ cells, which is different from the interaction and collaboration of $\mathrm{CD} 4^{+}$Tregs and $\mathrm{CD} 4^{+} \mathrm{T}$ cells and the collaboration between them really truly exists (21), yet several studies suggest that $\mathrm{CD}^{+}$Tregs act on $\mathrm{CD} 4^{+} \mathrm{T}$ cells or both $\mathrm{CD} 4^{+}$and $\mathrm{CD}^{+}{ }^{\mathrm{T}}$ cells $(22,23)$. For $\mathrm{CD} 8^{+}$Tregs, anti-PD- 1 can only block suppression of $\mathrm{CD}^{+} \mathrm{T}$ cells, but has no effect on $\mathrm{CD}^{+}{ }^{+} \mathrm{T}$ cells, even though the combination of anti-PD-1 and anti-CTLA-4 completely abrogates the suppressive effect on $\mathrm{CD}^{+} \mathrm{T}$ cells (24). We speculate that $\mathrm{CD} 8^{+}$Tregs may affect both $\mathrm{CD}^{+}$and $\mathrm{CD} 8^{+} \mathrm{T}$ cells in different ways, and the specific signaling pathways hence need to be clarified.

During the GVHD process, $\mathrm{CD}^{+}$Tregs are more remarkable than $\mathrm{CD}^{+}$Tregs to some extent, constituting a suppressive population and attenuating the severity of this disease (25). Prior studies have shown that not only does the proliferation of $\mathrm{CD}^{+}$ Tregs exceed that of $\mathrm{CD} 4^{+}$Tregs under certain conditions $(16,25)$, but the induced $\mathrm{CD}^{+}$Tregs $\left(\mathrm{CD}^{+}{ }^{+}\right.$iTregs) represent a larger proportion of induced Tregs (iTregs) in GVHD (26), which implies that it is easier to induce the formation of $\mathrm{CD}^{+}$iTregs in vitro and may help to address the insufficient source of $\mathrm{CD} 4^{+}$Tregs. In addition, the generation of $\mathrm{CD}^{+}$Tregs only occurs in the presence of allogeneic MHC (26) and correlates positively with the level of MHC disparity $(25,27)$. Further studies have shown that the antigen-specific regulatory abilities related to MHC-I only involve $\mathrm{CD}^{+}$Tregs (28). Importantly, $\mathrm{CD}^{+}$iTregs conditionally suppress allogeneic reactions without impairing general immunity against pathogen infection and residual tumor recurrence, in contrast to unselective $\mathrm{CD} 4^{+}$Tregs (29). Nevertheless, the $\mathrm{CD} 8^{\text {hi }}$ Tregs induced by CD40-activated B cells (30) and $\mathrm{CD}^{+}{ }^{+}$Tregs induced by allogeneic antigens in vitro (21) are both antigenspecific. We speculate that the proportion of $\mathrm{CD} 4^{+}$iTregs decides whether $\mathrm{CD}^{+}$Tregs are antigen-specific and such conflicting results may derive from the fact that there is a larger proportion of natural occurring Tregs (nTregs) in $\mathrm{CD}^{+}{ }^{+}$Tregs populations during GVHD, which present less targeted immunoregulation. There has been significant progress in our understanding of the immune regulation ability of $\mathrm{CD}^{+}$Tregs, becoming a hot topic for immune disorders.

\section{CD8 $^{+}$TREGS ALLEVIATING GVHD WHILE PRESERVING GVL EFFECTS}

Unlike $\mathrm{CD}^{+}{ }^{+}$Tregs, the mechanisms by which $\mathrm{CD} 8^{+}$Tregs alleviate GVHD are not entirely clear. Furthermore, growing evidence support the maintenance of GVL effect for $\mathrm{CD} 8^{+}$Tregs. Here, we summarize the regulatory mechanisms of $\mathrm{CD}^{+}$Tregs in GVHD and GVL effects (Figure 1).

\subsection{Initiation of CD8 ${ }^{+}$Tregs in GVHD}

A previous study illustrated that $\mathrm{CD} 8^{+} \mathrm{Foxp}^{-} \mathrm{T}$ cells can convert to $\mathrm{CD} 8^{+} \mathrm{Foxp} 3^{+}$Tregs with the help of DCs and TGF- $\beta$ from hosts in mesenteric lymph nodes after allo-HSCT (28). Gut-associated DCs induce CD $8^{+}$Tregs, depending on TGF- $\beta$ 


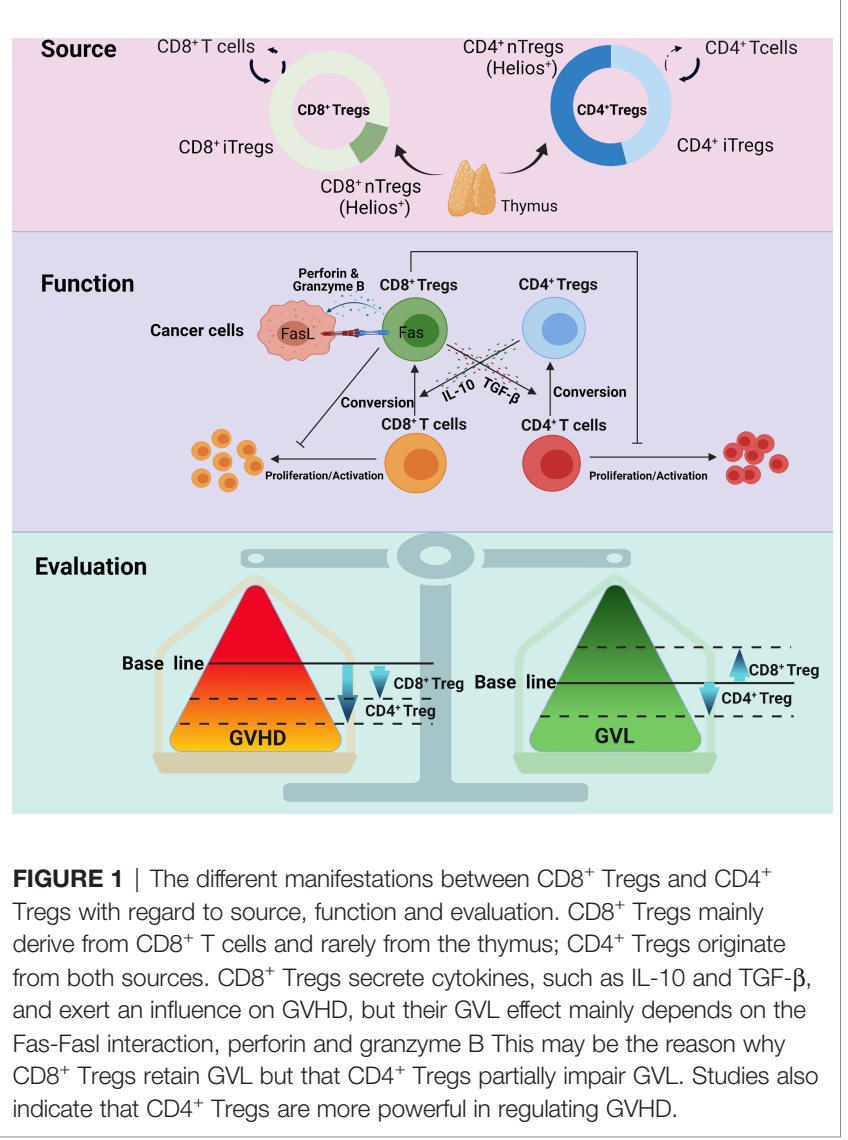

and retinoic acid (RA) (31). Therefore, antigen-presenting cells (APCs) may initiate induction, with cytokines assisting in the process. The $\mathrm{CD} 8^{+}$iTregs largely migrate and proliferate into the gastrointestinal tract and spleen, and the instability of Fxop3 will eventually result in conversion to effector cells, leading to GVHD (32). For skin allografts, $\mathrm{CD}^{+}$Tregs would mainly gather in draining lymph nodes (33). In summary, $\mathrm{CD}^{+}{ }^{+} \mathrm{Foxp}^{+}{ }^{+}$Tregs preferentially migrate to the site of immunoreaction; and communication with the local microenvironment is highly important, including the response to cytokines and cell contact.

\subsection{Intercellular Interactions of $\mathrm{CD}^{+}$ Tregs in GVHD}

In GVHD, $\mathrm{CD}^{+}{ }^{\mathrm{F}} \mathrm{Oxp}^{+}$Tregs exert protective effects principally by inhibiting $\mathrm{CD}^{+} \mathrm{T}$ cells and $\mathrm{B}$ cells, or including $\mathrm{CD} 8^{+} \mathrm{T}$ cells $(22$, 23). However, there are inconsistent results indicating that $\mathrm{CD} 8^{+}$ Tregs significantly suppress $\mathrm{CD} 8^{+} \mathrm{T}$ cells instead of $\mathrm{CD} 4^{+} \mathrm{T}$ cells (21). The contradictory results come from different measurement indexs and show discrepant effects in different aspects, which needs further study to acquire a credible answer. In the humanized GVHD mouse model, $\mathrm{CD}^{+}{ }^{+}$Tregs suppress $\mathrm{T}$ cell proliferation and inflammatory cytokine factor release for a long time in CTLA-4 (34) and PD-1 (24) dependent manners. In addition to T cell suppression, $\mathrm{CD}^{+}{ }^{+} \mathrm{Foxp}^{+}$Tregs induce $\mathrm{CD}^{+}$Tregs in vivo in a manner dependent on TGF- $\beta$ secretion by $\mathrm{CD} 8^{+} \mathrm{Foxp} 3^{+}$Tregs (33). Subsequent experiments show that $\mathrm{CD} 8^{+}$Tregs induce both $\mathrm{CD} 8^{+}$ and $\mathrm{CD}^{+}$Tregs in a GVHD model (22). $\mathrm{CD} 8^{+} \mathrm{CCR} 7^{+}$Tregs coexpressing CD45RA, Foxp3 and CD28 exert regulatory functions by suppressing TCR signal-mediated phosphorylation of ZAP70 in $\mathrm{CD}^{+} \mathrm{T}$ cells, the initial step of $\mathrm{T}$ cell activation, and decreasing intracellular calcium signaling (35). Phosphorylation of ZAP70 has also been found to play an important role in GVHD (36). Many results indicate that $\mathrm{CD} 8^{+}$Tregs is closely linked to DCs. $\mathrm{CD}^{+} \mathrm{Foxp}^{+}{ }^{+}$Tregs actually react with DCs by decreasing the expression of $\mathrm{CD} 40$ and $\mathrm{CD} 80 / \mathrm{CD} 86$, which also indicates that $\mathrm{CD}^{+} \mathrm{Foxp}^{+}{ }^{+}$Tregs contribute to the immune reactions $(28,33)$. Evidence demonstrates that $\mathrm{CD}^{+}$Tregs become conditioned to react with plasmacytoid DCs but not conventional DCs (16). However, whether discrepant responses influence their regulatory abilities regarding GVHD development in vivo remains unclear. $\mathrm{CD}^{+}$Tregs participate in other mechanisms, such as modulating Th17 (37), though more direct evidence for relevance to GVDH is needed.

\subsection{IL-10 and TGF- $\beta$ Immunoregulation in CD8 $^{+}$Tregs}

Among all regulatory factors, IL-10 and TGF- $\beta$ attract the most attention. As analyzed in human serum, IL-10 and TGF- $\beta$ exhibit a negative correlation with the occurrence of GVHD (38), which supports their regulatory roles. In vitro, $\mathrm{CD}^{+}$Tregs perform regulatory functions on allogeneic antigens in a fashion extremely dependent on IL-10 and TGF- $\beta$ but not cytotoxicity (30). In lupus patients, $\mathrm{CD} 8^{+} \mathrm{Foxp}^{+}$Tregs play a regulatory role dependent on TGF- $\beta$ after allo-HSCT, with no contact with $\mathrm{CD} 4^{+} \mathrm{T}$ cells (8). Similarly, IL-10 possesses strong regulatory abilities, and TGF- $\beta$ is significant for maintaining $\mathrm{CD}^{+}$Tregs (39). However, ex vivoinduced CD $8^{\text {hi }}$ Tregs decrease expression of IL-10 and TGF- $\beta$ in a humanized GVHD mouse model, which does not negate their contribution to GVHD (34). Researchers have also found that $\mathrm{CD}^{+}{ }^{+}$oxp $^{+}{ }^{+}$Tregs produce minor amounts of IL-10, ruling out toxicity in regulatory capacity (28). In conclusion, IL-10 and TGF- $\beta$ are important for $\mathrm{CD} 8^{+} \mathrm{Foxp}^{+}$Tregs, even though their expression is decreased. $\mathrm{CD} 88^{+} \mathrm{CD} 103^{+}$Tregs also depend on IL-10 and TGF- $\beta$ and show no relationship with cytotoxicity in an autoimmune disease model (40). In a cGVHD lupus mouse model, $\mathrm{CD}^{+} \mathrm{CD} 103^{+}$Tregs effectively alleviate the severity of GVHD, demonstrating the dependence on TGF- $\beta$ and IL-10 without any cytotoxicity, with cell contact being indispensable (41). However, it has also been reported that human alloantigen-induced $\mathrm{CD}^{+} \mathrm{CD}^{+} 103^{+}$Tregs are independent on IL-10 and TGF- $\beta$ in vitro as well as cytotoxicity (42). Overall, the inconsequent expression and dependence of IL-10 and TGF- $\beta$ and cytotoxicity in $\mathrm{CD} 8^{+}$Tregs remain uncertain and may be associated with different induction methods or complex inflammatory microenvironments.

\subsection{CD8 ${ }^{+}$Tregs in Preserving GVL Effects}

Mature donor T cells found in the graft become allo-activated during allo-HSCT, which leads to not only $\mathrm{T}$ cell proliferation and migration to target organs but also to activation for clearance of residual malignant cells, which is GVL effects (43). To date, it has been very difficult to separate GVHD and GVL effects. It is commonly reported that $\mathrm{CD} 4^{+}$Tregs impair the GVL effect when 
alleviating GVHD. Surprisingly, $\mathrm{CD}^{+}$Tregs maintain and even exert the GVL effects $(21,23,32)$, which is another distinctly superior aspect of $\mathrm{CD}^{+}$Tregs and indirectly reflects antigenic specificity. It has also been reported that $\mathrm{CD}^{+}$Tregs virtually exert GVL effects through the Fas-FasL and perforin-granzyme B pathways without affecting general immunity but that $\mathrm{CD} 4^{+}$ Tregs do not (34), which is consistent with results that the CD8 ${ }^{+}$ iTregs retain cytotoxicity and preserve the GVL effect (22). Further results demonstrate that the cytotoxicity of $\mathrm{CD} 8^{+}$Tregs in tumor cell killing is the basis of GVL effects and that the combination of $\mathrm{CD}^{+}{ }^{+}$Tregs and $\mathrm{CD} 8^{+}$Tregs is an ideal therapy that would more effectively prevent GVHD and preserve GVL effects (21).

\section{CD8 $^{+}$TREGS HETEROGENEITY}

In general, the $\mathrm{CD}^{+}$Tregs phenotype is identified, as $\mathrm{CD} 4^{+} \mathrm{CD} 25^{\text {high }} \mathrm{Foxp}^{+}$and/or CD $127^{\text {low/- }}$ and Foxp 3 is necessary for maintaining regulatory functions, but $\mathrm{CD} 8^{+}$ Tregs display much more heterogeneity in phenotype and function $(44,45)$. There are diverse types of $\mathrm{CD}^{+}$Tregs for different disease conditions, presenting various effects $(33,46-$ 48). (Table 1) Several $\mathrm{CD}^{+}$Tregs could naturally occur and participate in normal living activities. And researcher have found that there are abnormal CD8 ${ }^{+}$Tregs in several circumstances, including decreasing in GVHD and autoimmune disease patients, while elevating in patients with cancers. But some other $\mathrm{CD}^{+}$Tregs such as $\mathrm{CD} 8^{+} \mathrm{CD} 103^{+}$Tregs could be cultured in vitro and infused back for disease therapy.

\section{1 $\mathrm{CD}^{+} \mathrm{CD}^{+} 5^{+} \mathrm{Foxp}^{+}$Tregs}

$\mathrm{CD} 25^{+} \mathrm{T}$ cells have a unique regulatory function mainly via consuming endogenous IL-2. In contrast, previous studies have found that $\mathrm{CD} 8{ }^{+} \mathrm{CD} 25^{+} \mathrm{T}$ cells and $\mathrm{CD} 4^{+} \mathrm{CD} 25^{+} \mathrm{T}$ cells play an active role in the GVHD process $(67,68)$, suggesting that CD25 is insufficient to identify $\mathrm{CD} 8^{+}$Tregs. The regulatory functions of $\mathrm{CD} 4^{+}$Tregs have been proven to be extremely dependent on Fxop3 (69), which is considered a regulatory marker for Tregs. $\mathrm{CD} 8^{+} \mathrm{CD} 25^{+} \mathrm{Foxp}^{+}$Tregs in vivo have similar regulatory ability and express CTLA-4 and TNFR2 (49), and induced CD ${ }^{+} \mathrm{CD} 25^{+}$Foxp $^{+}{ }^{+}$Tregs similarly express CTLA-4, PD-1, PD-L1, and TNFR2 in vitro. Furthermore, expression of PD-L1 and TNFR2 is imperative for regulatory functions, which are maintained by IL- 2 and TGF- $\beta(33,39,50)$. Most importantly, there is considerable evidence showing that $\mathrm{CD} 8^{+} \mathrm{CD} 25^{+}$Foxp $3^{+}$ Tregs effectively regulate $\operatorname{GVHD}(25,29,51)$. Despite expressing GITR and CTLA- 4 like CD $4^{+}$Tregs, $\mathrm{CD} 8^{+} \mathrm{CD} 25^{+}$Foxp $^{+}{ }^{+}$Tregs rarely express Helios regarded as a marker for nTregs from the thymus, which means that almost all $\mathrm{CD} 8^{+} \mathrm{CD} 25^{+} \mathrm{Foxp}^{+}$Tregs are induced to generate, relying on the receptors of IL-2 and TGF- $\beta(26,28)$.

\section{2 $\mathrm{CD}^{+} \mathrm{CD} 103^{+}$Tregs}

CD103 is generally expressed on the surface of partial T cells and DCs and is related to tissue location as the receptor of E-cadherin. Experiments have identified that expression of CD103 on $\mathrm{CD}^{+}$ Tregs contributes to local regulatory abilities (70) and that expression on effector $\mathrm{CD}^{+} \mathrm{T}$ cells aids in entry into and destruction of the intestinal epithelium in animal models of GVHD (71), which indirectly supports the same role for $\mathrm{CD}^{+} \mathrm{CD} 103^{+}$Tregs. $\mathrm{CD}^{+} \mathrm{CD}^{+} 3^{+}$Tregs usually derive from $\mathrm{CD}^{+} \mathrm{CD}^{-} 103^{-} \mathrm{T}$ cells, and $\mathrm{CD} 103$ is regarded as the marker of $\mathrm{CD}^{+} \mathrm{CD}^{+} 3^{+}{ }^{+}$Tregs (42). The regulatory ability of $\mathrm{CD} 8^{+}$Tregs is independent of Foxp3; for CD8 ${ }^{+}$Foxp $3^{-}$Tregs, CD103 is needed and seemingly remedies Foxp3 deficiency (40). CD103 expression induced by human cord blood mononuclear cell (CBMC) on

TABLE 1 | Heterogeneity of CD8 ${ }^{+}$Tregs.

\begin{tabular}{|c|c|c|c|c|c|}
\hline Phenotype & Features & Ways to acquire & Source & $\begin{array}{l}\text { Effect in } \\
\text { GVHD }\end{array}$ & Ref. \\
\hline $\mathrm{CD}^{+} \mathrm{CD}^{+} 5^{+} \mathrm{Foxp}^{+}$ & $\begin{array}{l}\text { Expressing CTLA-4, TNFR2 and other various surface } \\
\text { makers for different situations such as GITR, CD44, } \\
\text { CD102 and CD133, dependent on IL-2 and TGF- } \beta \\
\text { for phenotype and function }\end{array}$ & $\begin{array}{l}\text { Naturally occurring and } \\
\text { induced }\end{array}$ & Humans and Mice & Yes & $\begin{array}{l}(25,26,28 \\
29,31,33 \\
39,49-51)\end{array}$ \\
\hline $\mathrm{CD}^{+}{ }^{+} \mathrm{CD} 103^{+}$ & $\begin{array}{l}\text { CD103 may compensate the deficiency of Foxp3 in } \\
\text { regulating immune response, and dependent on } \\
\text { IL-2 and TGF- } \beta \text { and is more stable than CD4 }{ }^{+} \text {Tregs to } \\
\text { some extent. }\end{array}$ & Induced & Humans and Mice & Yes & $\begin{array}{c}(40-42,52, \\
53)\end{array}$ \\
\hline CD8 ${ }^{\text {hi }}$ Tregs & $\begin{array}{l}\text { Antigen-specific and expressing CD25, Foxp3 and CTLA- } \\
4 \text { extremely similar to CD } 8^{+} \mathrm{CD} 25^{+} \text {Foxp3 }{ }^{+} \text {Tregs }\end{array}$ & Induced & Humans & Yes & $(30,34,54)$ \\
\hline $\mathrm{CD}^{+}{ }^{\mathrm{C}} \mathrm{CD} 45 \mathrm{RC}^{\mathrm{low} /-}$ & $\begin{array}{l}\text { Expressing foxp3 and dependent on production of IL-10 } \\
\text { and TGF- } \beta\end{array}$ & $\begin{array}{l}\text { Naturally occurring and } \\
\text { induced }\end{array}$ & Humans and Rats & Yes & $(16,55)$ \\
\hline $\mathrm{CD}^{+} \mathrm{CD} 28^{- \text {-low }}$ & $\begin{array}{l}\text { Less dependent on Foxp3 for immunoregulatory } \\
\text { properties, and other molecules may be } \\
\text { highly relevant }\end{array}$ & $\begin{array}{l}\mathrm{CD}^{+} \mathrm{CD} 28^{\text {low }} \text { Tregs are } \\
\text { more likely to occur } \\
\text { naturally, and } \\
\mathrm{CD} 8^{+} \mathrm{CD} 28^{-} \text {Tregs tend } \\
\text { to be induced }\end{array}$ & Humans and Mice & $\begin{array}{l}\text { not } \\
\text { described }\end{array}$ & $(56-59)$ \\
\hline $\mathrm{CD}^{+}{ }^{+} \mathrm{CD} 122^{+}$ & $\begin{array}{l}\text { Dependent on PD-1 and CD28 but not Foxp3, } \\
\text { which is related to recognition of CD80/86 and } \\
\text { production of IL-10; sometimes more powerful } \\
\text { than CD4 }{ }^{+} \text {Tregs }\end{array}$ & Induced & $\begin{array}{l}\text { Mice (human } \mathrm{CD}^{+} \mathrm{CXCR} 3^{+} \\
\text {Tregs may be the counterparts } \\
\text { of mice } \mathrm{CD} 8^{+} \mathrm{CD} 122^{+} \text {Tregs) }\end{array}$ & $\begin{array}{l}\text { not } \\
\text { described }\end{array}$ & $(60-66)$ \\
\hline
\end{tabular}


$\mathrm{CD}^{+} \mathrm{T}$ cells has been proven, and culture conditions can drive differentiation of $\mathrm{CD}^{+} \mathrm{CD} 25^{+} \mathrm{Foxp}^{+} \mathrm{CD} 103^{+}$Tregs from human CBMCs (52). During GVHD, $\mathrm{CD}^{+} \mathrm{CD} 103^{+}$Tregs induced by TGF- $\beta$ effectively alleviate disease severity; they are more stable than $\mathrm{CD}^{+}$Tregs because they express CD103 (41). CD39 also plays a regulatory role in $\mathrm{CD}^{+} \mathrm{CD}_{103}{ }^{+}$Tregs, and anti-CD39 abrogates regulatory abilities (53).

\subsection{CD8 ${ }^{\text {hi }}$ Tregs}

CD ${ }^{\text {hi }}$ Tregs induced by CD40-activated B cells are antigenspecific, and functional markers, such as CD25, Foxp3, CTLA-4, GITR, IL-10, and TGF- $\beta$, are upregulated (30). These findings are consistent with the results that $\mathrm{CD} 8{ }^{\text {hi }}$ Tregs induced in vitro with expression of CD25, Foxp3 and CTLA-4 alleviate GVHD without affecting general immunity and graft-versus-tumor activity (34). CD8 ${ }^{\text {hi }}$ Tregs are also induced by human monocyte-derived suppressor cells (HuMDSCs) in vivo, showing upregulation of CD25, Foxp3 and CD103 (54). Despite plentiful evidence for the existence of CD8 ${ }^{\text {hi }}$ Tregs, it is uncertain whether they are entirely different from $\mathrm{CD} 8^{+} \mathrm{CD} 25^{+} \mathrm{Foxp}^{+}$Tregs. Indeed, both express the phenotype analogously, and expression of CD25 and Foxp3 may be concomitant.

\subsection{CD8 ${ }^{+}$CD45RC $C^{\text {low/- }}$ Tregs}

Natural $\mathrm{CD}^{+} \mathrm{CD} 45 \mathrm{RC}^{\text {low/- }}$ Tregs coexpressing Foxp3 and CTLA-4 indicate an immunosuppressive function (55). Similarly, $\mathrm{CD}^{+} \mathrm{CD} 45 \mathrm{RC}^{\text {low/- }}$ Tregs induced in vitro richly expressing Foxp3, CD25, CD103, CD122 and GITR have been identified to play a vital role in GVHD (16).

\subsection{Other Subgroups of $\mathrm{CD}^{+}$Tregs}

For some types of $\mathrm{CD}^{+}$Tregs, direct evidence to identify their immunomodulatory effects in GVHD is currently lacking.

\subsection{1 $\mathrm{CD}^{+} \mathrm{CD} 28^{-/ \text {low }}$ Tregs}

CD28 plays a key role as a costimulatory signal in adaptive immunity by activating $\mathrm{T}$ cells. However, a subset of $\mathrm{CD}^{+}$ Tregs was recently identified as $\mathrm{CD}_{2} 8^{-}$or $\mathrm{CD} 28^{\text {low }}$. In that study, $\mathrm{CD} 8^{+} \mathrm{CD} 28^{-}$Tregs developed naturally in vivo with expression of CD25, Foxp3 and CTLA-4, along with low expression of CD127 and high expression of CD122 $(56,57)$. $\mathrm{CD} 8^{+} \mathrm{CD} 28^{-}$Tregs can be induced in vitro without expression of Foxp3, whereas $\mathrm{CD} 4^{+}$Tregs cannot. GITR expression is crucial for their generation (58). CD39 (ectonucleoside triphosphate diphosphohydrolase 1; encoded by ENTPD1) binds extracellular ATP (eATP) and converts it to extracellular adenosine which is expressed by various immune cells and non-immune cells (72) and expression of CD39 plays an important role in $\mathrm{CD}^{+} \mathrm{CD} 28$ Tregs without Fxop3, CD103 and CD122 expression (59). Regarding the origin of $\mathrm{CD}^{+} \mathrm{CD} 28^{-}$Tregs, researchers have suggested that they may derive from $\mathrm{CD} 8^{+} \mathrm{CD} 28^{-} \mathrm{T}$ cells associated with IL-10 secretion but not from $\mathrm{CD} 8^{+} \mathrm{CD} 28^{+} \mathrm{T}$ cells (73). Regardless, $\mathrm{CD} 8^{+} \mathrm{CD} 28^{\text {low }}$ Tregs are present in the thymus locally without recirculating from the periphery; they express Helios but not traditional $\mathrm{CD}^{+}$Treg markers such as Foxp3, CD25 and neuropilin-1 (74), and these cells tend to be generated from the thymus (57). In general, $\mathrm{CD}^{+} \mathrm{CD} 28^{-}$Tregs and $\mathrm{CD} 8^{+} \mathrm{CD} 28^{\text {low }}$ Tregs differ from each other, and their regulatory capacities and application in GVHD should be studied further.

\subsection{2 $\mathrm{CD}^{+} \mathrm{CD} 122^{+}$Tregs}

CD122 is usually known as the beta chain of IL-2 or IL-15. Initially, transferred $\mathrm{CD} 8{ }^{+} \mathrm{CD} 122^{+} \mathrm{T}$ cells prevent the development of activated $\mathrm{CD} 9^{+} \mathrm{T}$ cells, indicating a single group of regulatory $\mathrm{T}$ cells (60). Subsequent experiments discovered the importance of PD-1 and CD28 for regulatory abilities, and $\mathrm{CD} 8^{+} \mathrm{CD} 122^{+} \mathrm{PD}-1^{+} \mathrm{T}$ cells can be distinguished from $\mathrm{CD}^{+} \mathrm{CD} 122^{+} \mathrm{T}$ cells (61). In addition, CD28 may help $\mathrm{CD}^{+} \mathrm{CD} 122^{+}$Tregs recognize target cells by interacting with CD80/86, excluding the regulatory function of CTLA-4 and ICOS, but Foxp3 is not expressed in $\mathrm{CD}^{+} \mathrm{CD} 122^{+}$Tregs (62). It is worth noting that previous studies have shown that the addition of PD-L1 enhances IL-10 expression, but another study indicated that anti-PD-1 was unable to inhibit IL-10. These discrepancies may be due to different induction methods, thus affecting the response to $\mathrm{PD}-1$ signals. IL-10 expression is strongly reduced by blocking $\mathrm{CD} 28$, which indicates that the interaction between CD28 and CD80/86 is indispensable for regulatory abilities (63). Considering the discrepancy between humans and animals, $\mathrm{CD} 8^{+} \mathrm{CD} 122^{+}$Tregs in mice correspond to $\mathrm{CD}^{+}{ }^{+} \mathrm{CXCR}^{+}{ }^{+}$Tregs in humans (64). In allotransplant animal models, the regulatory abilities of $\mathrm{CD}^{+} \mathrm{CD} 122^{+}$Tregs are superior to those of $\mathrm{CD} 4^{+}$Tregs in terms of the production of IL-10 (65). In addition, emodin can alleviate immunological rejections by inducing $\mathrm{CD}^{+} \mathrm{CD} 122^{+}$Tregs and $\mathrm{CD} 4^{+}$Tregs in vivo (66). However, the exact function of $\mathrm{CD} 8^{+} \mathrm{CD} 122^{+}$Tregs in GVHD remains unclear, and further study is urgently needed.

\section{CD8 $^{+}$TREGS OPTIMIZATION}

Continuing research on $\mathrm{CD} 8^{+}$Tregs to support a stable state and enhanced regulatory ability is needed to attenuate GVHD effectively, which means the need for $\mathrm{CD}^{+}$Tregs optimization. In addition, ensuring safety is of much significance. Attempts for $\mathrm{CD}^{+}$Tregs improvement are provided in Figure 2.

\subsection{Promoting Generation}

Several cytokines have been described as playing a role in $\mathrm{CD}^{+}$ Tregs. IL-2 is a proinflammatory factor, and recent studies have demonstrated its regulatory functions in GVHD. Expansion of $\mathrm{CD} 4{ }^{+}$Tregs induced by IL-2 occurs during GVHD treatment (75, 76), and the ability of this cytokine to regulate $\mathrm{CD} 8^{+}$Tregs needs to be further studied. Rapamycin and IL-2 have been described as expanding $\mathrm{CD}^{+}{ }^{+}$Foxp $3^{+}$Tregs in vivo, contributing to GVHD severity alleviation (28). Consistently, rapamycin enhances the immunoregulatory properties of $\mathrm{CD} 8^{+} \mathrm{Foxp} 3^{+}$Tregs (32). Rapamycin and IL-2 show a limited effect on the stability of $\mathrm{CD}^{+}{ }^{+}$Foxp $^{+}{ }^{+}$Tregs compared to $\mathrm{CD}^{+}$Tregs; thus, the former may not completely eradicate GVHD due to conversion into effector $\mathrm{T}$ cells (32). Moreover, $\mathrm{CD} 8^{+} \mathrm{CD} 45 \mathrm{RC}^{\text {low/- }}$ Tregs prevent GVHD via extensive regulatory functions and proliferation abilities 


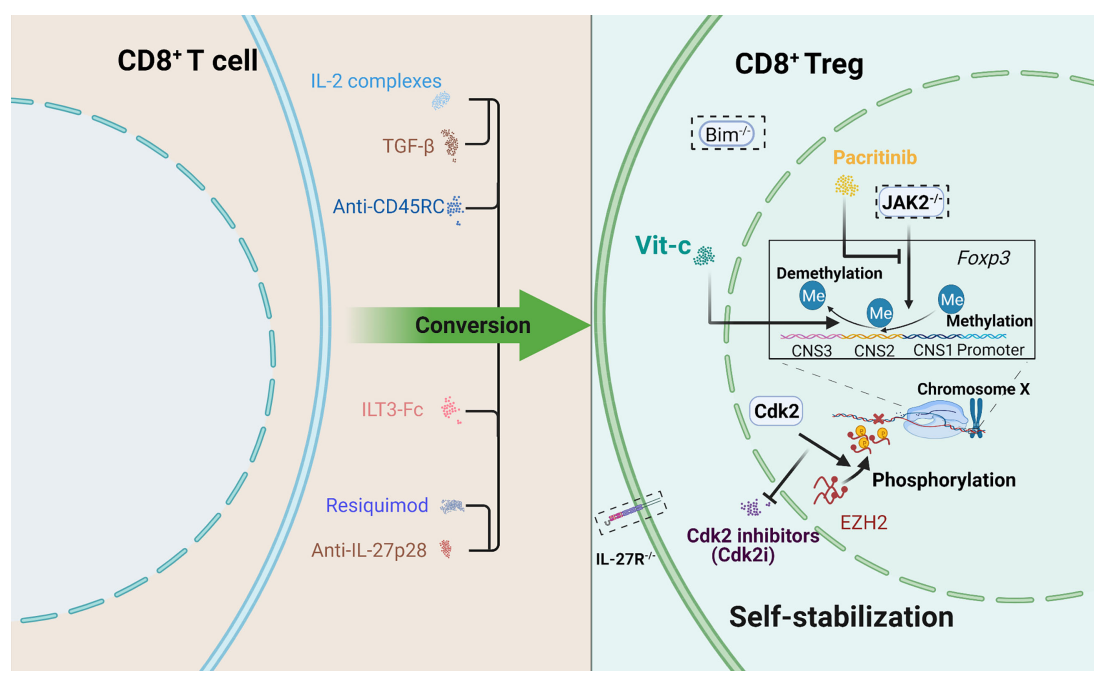

FIGURE 2 | Schematic depicting several attempts to optimize CD8 ${ }^{+}$Tregs. Two aspects were included: promoting conversion and maintaining self-stabilization. How to maintain stable expression of Foxp3 is a priority. Some approaches offer new therapeutic ideas for the clinic. A dotted box indicates gene knockout.

induced by rapamycin (16). A study on all-trans retinoic acid (ATRA) suggested that it promotes Foxp3 demethylation to increase $\mathrm{CD} 4^{+}$Tregs production (77). In GVHD models, ATRA promotes $\mathrm{CD} 4^{+}$Tregs generation to effectively alleviate GVHD but is unfavorable for $\mathrm{CD}^{+}$Tregs (78), which in turn indicates a differential response to ATRA by $\mathrm{CD}^{+}$and $\mathrm{CD}^{+}$Tregs and suggesting this possibility in vivo. In addition to blocking IL-6 for $\mathrm{CD}^{+}$Tregs expansion (79), deficiency in IL-27 signals enhances the proliferation of both $\mathrm{CD} 4^{+}$Tregs and $\mathrm{CD}^{+}$Tregs, suppressing the GVHD process (80). Moreover, coadministration of anti-IL-27 and resiquimod, agonists of Toll-like receptor 7 , increases the number of $\mathrm{CD}^{+}$and $\mathrm{CD}^{+}$Tregs and alleviates GVHD (81). Nevertheless, IL27-primed $\mathrm{CD}^{+}$Tregs show immunoregulatory properties to provide a protective role in GVHD (82). IL-27 acts on multiple cells, including proinflammatory and regulatory cells and the final results depend on the overwhelming mechanism. It also has been speculated that IL-27 exerts diverse effects in different stages of the GVHD process. In addition, transient anti-CD45RC treatment appears to induce $\mathrm{CD} 45^{\text {hi }} \mathrm{T}$ cell apoptosis and preserve $\mathrm{CD} 8^{+} \mathrm{CD} 45^{\text {low/- }}$ Tregs and $\mathrm{CD} 4^{+} \mathrm{CD} 45^{\text {low/- }}$ Tregs, enhancing regulatory ability (83). Immunoglobulin-like transcript 3 (ILT3) is an inhibitory receptor expressed on antigen-presenting cells (APCs), and some studies have identified the effect of ILT3-Fc in reducing GVHD, which may be due to induction of $\mathrm{CD}^{+}$Tregs (84). Inhibition of Cdk2 inactivates EZH2 and induces epigenetic regulation of Foxp3, leading to more $\mathrm{CD} 8^{+}$Tregs generation and GVHD prevention (85). These results reveal an unexpected mechanism by which Cdk2 inhibitors induce $\mathrm{CD} 8^{+}$Tregs. From another point of view, this is a great attempt to change the epigenetic characteristics of $\mathrm{CD} 8^{+}$Tregs.

\subsection{Strengthening Stabilization}

Pacritinib, a blocking agent of Janus kinase 2 (JAK2), has been reported to prevent GVHD while preserving the GVL effects
(86). $\mathrm{CD}^{+}$Tregs generation is restrained by JAK2 signals, and the same effect on $\mathrm{CD}^{+}{ }^{+} \mathrm{Foxp}^{+}{ }^{+}$Tregs indicates that blockade of JKA2 signals in $\mathrm{CD}^{+} \mathrm{Foxp}^{+}$Tregs may effectively alleviate GVHD while preserving the GVL effects (22). Regarding mechanisms, blocking JAK2 signaling enhances the stability of $\mathrm{CD}^{+}{ }^{+}$Foxp $^{+}{ }^{+}$Tregs with upregulated expression of CD25, and even generates more $\mathrm{CD} 4^{+}$and $\mathrm{CD} 8^{+}$Tregs, which correlates with higher expression of neuropilin-1, a marker of Tregs, as well as demethylation of CNS2. An analogous mechanism has been reported for vitamin C (Vit-c), which exerts an effect on $\mathrm{CD}_{4}{ }^{+}$ Tregs (87), and the CNS2 region plays a significant role in expression of Foxp3 (88). However, it remains unclear whether Vit-c alleviates GVHD by affecting $\mathrm{CD}^{+}{ }^{+} \mathrm{Foxp}^{+}{ }^{+}$Tregs. Vit-c as the cofactor of TET enzymes treatment can maintain demethylation of CNS2, and stabilize the expression of Foxp3 in $\mathrm{CD}^{+}$Tregs, thus promoting expression of CD25, Nrp1, Helios, CTLA-4 and PD-1 in vitro, preventing GVHD and maintaining the GVL effects (23). Indeed, Bim expression is able to impact Tregs by restraining proliferation and regulating apoptosis (89), which also contributes to imbalance between Tregs and effector $\mathrm{T}$ cells (90). Recent studies have found that Bim deficiency largely prolongs the survival of $\mathrm{CD}^{+}{ }^{+}$Tregs, thus enhancing protection from GVHD (18). Notably, it is very different from earlier studies aiming at the stability of Foxp3.

\subsection{Optimizing Function}

With the maturation of immune cell-based targeting therapy technology, chimeric antigen receptor-redirected $\mathrm{T}$ cells (CART) have been successfully used for the treatment of hematological malignancies, with curative effects $(91,92)$. HLA-A2-specific CAR $\mathrm{CD}^{+}$Tregs have greater regulatory GVHD abilities than polyclonal $\mathrm{CD} 4^{+}$Tregs (93), and accordingly, HLA-A2-specific CAR CD $8^{+}$Tregs are reported to prevent GVHD more effectively (94). However, there have been no studies to date demonstrating 
the influence on general immunity and the GVL effects. Engineered Tregs (eTregs) might offer an effective means to obtaining sufficient Tregs in the clinic. Much evidence shows that $\mathrm{CD}^{+}$eTregs derived from lentiviral transfection coexpressing Helios and Foxp3 effectively alleviate GVHD in a manner slightly superior to that of $\mathrm{CD}^{+}$eTregs (95). Furthermore, different isoforms of Helios show disparate influences on $\mathrm{CD}^{+}$and $\mathrm{CD}^{+}$Tregs, which should be taken into consideration in future studies.

\section{CONCLUSION AND PROSPECTS}

The ability to prevent GVHD without weakening GVL effects renders $\mathrm{CD} 8^{+}$Tregs superior to $\mathrm{CD} 4^{+}$Tregs, including enhancing GVL effects. Inducing $\mathrm{CD} 8^{+}$Tregs may ensure an adequate cell source. Although there is no doubt that $\mathrm{CD} 8^{+}$Tregs will be applied extensively for treating GVHD in the clinic, some obstacles and unsolved mechanisms remain to be explored. First, $\mathrm{CD} 8^{+}$Tregs are only present for a short time in GVHD, and such instability strongly affects application. Thus, we need feasible methods to stabilize phenotypes and regulatory abilities or to block factors that contribute to $\mathrm{CD}^{+}$Tregs conversion. Second, most $\mathrm{CD} 8^{+}$Tregs do not express Foxp3, and the exact function of Foxp3 in $\mathrm{CD}^{+}$ Tregs remains unclear. Hence, other specific markers for $\mathrm{CD}^{+}$ Tregs need to be identified to improve and facilitate their induction and isolation to achieve the best treatment in the clinic. Third, $\mathrm{CD}^{+}$ Tregs can produce several inflammatory cytokines, such as IFN- $\gamma$, IL-2 and TNF- $\alpha(26,28,29,49)$, which indicates that GVHD risk should be taken into consideration and that ensuring safe therapy needs more study. Optimal regulatory cell design may result in an ideal outcome, such as the combination of $\mathrm{CD}^{+}$and $\mathrm{CD} 4^{+}$Tregs exerting ameliorative results. In addition, microRNAs participate in regulating $\mathrm{CD}^{+}$Tregs function by regulating cytokine secretion or transcription factor expression; for example, miR-27b-3p and miR$340-5 p$ negatively regulate the IL- 10 level, and miR-330-3p acts on TGF- $\beta$ expression (96). Foxp 3 and CTAL- 4 are negatively regulated by miR-335, miR-9 and miR-155 (97). Overall, the effect of microRNAs on $\mathrm{CD}^{+}$Tregs may influence the development of GVHD, and more evidence is needed.

For GVHD treatment, more studies are needed to identify different effects of drugs on $\mathrm{CD}^{+}{ }^{+}$Tregs to improve outcomes of GVHD, because of the clearance or inhibition of these cells by immunosuppressive agents. For instance, cyclosporine (28) and cyclophosphamide suppress the generation and function of $\mathrm{CD}^{+}$ Tregs (98). However, $\mathrm{CD} 8^{+} \mathrm{CD} 28^{-}$Tregs are not influenced by methylprednisolone (58), which indicates their superiority in the combined application of $\mathrm{CD} 8^{+} \mathrm{CD} 28^{-}$Tregs and glucocorticoids for GVHD. In addition, extracorporeal photopheresis (ECP), which is superior to other strategies because of the lack of bioactive materials, has been adopted to cure GVHD in the clinic, as ECP enhances the generation of both $\mathrm{CD}^{+}$and $\mathrm{CD} 8^{+}$Tregs (99). Nonetheless, the detailed mechanisms need to be elucidated.

In addition to immunoregulation to alleviate GVHD, how to exert powerful GVL effects remains another challenge for the development of cellular therapy technology. CAR CD ${ }^{+}$Tregs effectively alleviate GVHD, making it possible to achieve efficient GVL effects via CAR-T technology. However, immunosuppression or combination therapy may restrict $\mathrm{CD}^{+}$Tregs in vivo, and effective methods need to be identified for $\mathrm{CD}^{+}$Tregs application. Methods to eradicate such restriction may avoid tumor recurrence. In general, we should realize that the most abundant $\mathrm{CD} 8^{+}$Tregs are generated by autologous $\mathrm{CD}^{+} \mathrm{T}$ cells, and it is the key to constructing a suitable microenvironment in vivo.

Other approaches to strengthen immunoregulation capacity as well as novel solutions may be found in the interaction between $\mathrm{CD}^{+}$Tregs and other immune cells; for example, the regulatory function of mesenchymal stem cells (MSCs) is related to both CD4 ${ }^{+}$ and $\mathrm{CD}^{+}$Tregs (100). In a human study of refractory cGVHD, MSC infusion induced a higher proportion (101) and enhanced the regulatory capacities of $\mathrm{CD}^{+}$Tregs, subsequently suppressing the proliferation and activation of $\mathrm{CD}^{+}$effector T cells and effectively alleviating cGVHD (102). Therefore, MSC-primed CD8 ${ }^{+}$Tregs may have much more potential, and other cell types have been proven to influence $\mathrm{CD} 8{ }^{+}$Tregs function. Deficiency in liver kinase $\mathrm{B} 1$ (Lka1) in DCs greatly enhances the generation of $\mathrm{CD}^{+}$Tregs while maintaining high levels of Nrp1 and Helios, which indicates that the cells originate from the thymus (103). Lkal may be a limitation for $\mathrm{CD}^{+}$Tregs, and therapy targeting Lka1 will overcome the intrinsic defect in the generation of $\mathrm{CD} 8^{+}$Tregs in GVHD. Moreover, human CD $36^{\text {hi }}$ monocytes induce CD8 ${ }^{+}$Tregs in vitro and ameliorate GVHD by suppressing $\mathrm{T}$ cell proliferation, which also indicates that monocytes may assist in regulatory functions (104). However, the underlying mechanisms of cellular interactions in vivo need to be further investigated.

Taken together, we believe that $\mathrm{CD}^{+}$Tregs are powerful players in immune regulation and should be developed further through deeper and more systematic studies. Although much work is needed, all advances will provide understanding of $\mathrm{CD} 8^{+}$ Tregs and optimization for $\mathrm{CD}^{+}$Tregs to ensure better outcomes for cell therapy in transplantation.

\section{AUTHOR CONTRIBUTIONS}

The manuscript was conceptualized by XZ and SY. WW wrote the majority of the manuscript, and $\mathrm{XW}$ and $\mathrm{TH}$ cowrote the manuscript. The figures were designed by WW and drawn with XW and RW. YD and QG produced the tables. All authors contributed to the article and approved the submitted version.

\section{FUNDING}

This work was supported by the National Natural Science Foundation of China International Exchange and Cooperation Key Project (Grant No. 82020108004), National Center for Clinical Medicine Research on Blood System Diseases 2020 Open Project (Key Project) (Grant No. 2020ZKZC02), National Key Research Program "Stem Cell and Translational Research” Key Special Project (Grant No. 2017YFA0105502). 


\section{REFERENCES}

1. Gambineri E, Torgerson TR, Ochs HD. Immune Dysregulation, Polyendocrinopathy, Enteropathy, and X-Linked Inheritance (IPEX), a Syndrome of Systemic Autoimmunity Caused by Mutations of FOXP3, a Critical Regulator of T-Cell Homeostasis. Curr Opin Rheumatol (2003) 15:430-5. doi: 10.1097/00002281-200307000-00010

2. Setoguchi R, Hori S, Takahashi T, Sakaguchi S. Homeostatic Maintenance of Natural Foxp3(+) CD25(+) CD4(+) Regulatory T Cells by Interleukin (IL)-2 and Induction of Autoimmune Disease by IL-2 Neutralization. J Exp Med (2005) 201:723-35. doi: 10.1084/jem.20041982

3. Shevach EM. Immunology. Regulating Suppression. Sci (American Assoc Advancement Science) (2008) 322:202-3. doi: 10.1126/science.1164872

4. Gutiérrez-Hoya A, López-Santiago R, Vela-Ojeda J, Montiel-Cervantes L, Rodríguez-Cortés O, Rosales-García V, et al. Role of CD8 Regulatory T Cells Versus Tc1 and Tc17 Cells in the Development of Human Graft-VersusHost Disease. J Immunol Res (2017) 2017:1-11. doi: 10.1155/2017/1236219

5. Seidkhani-Nahal A, Noori-Zadeh A, Bakhtiyari S, Khosravi A. Frequency of CD8+ Regulatory T Cells in the Multiple Sclerosis Patients: A Systematic Review and Meta-Analysis. Acta Neurol Belg (2019) 119:61-8. doi: 10.1007/ s13760-018-1028-3

6. Shimokawa C, Kato T, Takeuchi T, Ohshima N, Furuki T, Ohtsu Y, et al. CD8+ Regulatory T Cells are Critical in Prevention of AutoimmuneMediated Diabetes. Nat Commun (2020) 11:1922. doi: 10.1038/s41467020-15857-x

7. Yesillik S, Agrawal S, Gollapudi SV, Gupta S. Phenotypic Analysis of CD4+ Treg, CD8+ Treg, and Breg Cells in Adult Common Variable Immunodeficiency Patients. Int Arch Allergy Imm (2019) 180:150-8. doi: $10.1159 / 000501457$

8. Zhang L, Bertucci AM, Ramsey-Goldman R, Burt RK, Datta SK. Regulatory T Cell (Treg) Subsets Return in Patients With Refractory Lupus Following Stem Cell Transplantation, and TGF-Beta-Producing CD8+ Treg Cells are Associated With Immunological Remission of Lupus. J Immunol (2009) 183:6346-58. doi: 10.4049/jimmunol.0901773

9. Howlett-Prieto Q, Feng X, Kramer JF, Kramer KJ, Houston TW, Reder AT. Anti-CD20 Therapy Corrects a CD8 Regulatory T Cell Deficit in Multiple Sclerosis. Mult Scler J (2021) 27(14):2170-9. doi: 10.1177/13524585211003301

10. Jadidi-Niaragh F, Yousefi M, Memarian A, Hojjat-Farsangi M, Khoshnoodi J, Razavi SM, et al. Increased Frequency of CD8+ and CD4+ Regulatory T Cells in Chronic Lymphocytic Leukemia: Association With Disease Progression. Cancer Invest (2013) 31:121-31. doi: 10.3109/07357907.2012.756110

11. Muthu Raja KR, Kubiczkova L, Rihova L, Piskacek M, Vsianska P, Hezova R, et al. Functionally Suppressive CD8 T Regulatory Cells are Increased in Patients With Multiple Myeloma: A Cause for Immune Impairment. PLoS One (2012) 7:e49446. doi: 10.1371/journal.pone.0049446

12. Zahran AM, Nafady-Hego H, Mansor SG, Abbas WA, Abdel-Malek MO, Mekky MA, et al. Increased Frequency and FOXP3 Expression of Human $\mathrm{CD} 8+\mathrm{CD} 25$ High + $\mathrm{T}$ Lymphocytes and its Relation to CD4 Regulatory T Cells in Patients With Hepatocellular Carcinoma. Hum Immunol (2019) 80:510-6. doi: 10.1016/j.humimm.2019.03.014

13. Zhang S, Ke X, Zeng S, Wu M, Lou J, Wu L, et al. Analysis of CD8+ Treg Cells in Patients With Ovarian Cancer: A Possible Mechanism for Immune Impairment. Cell Mol Immunol (2015) 12:580-91. doi: 10.1038/cmi.2015.57

14. Meloni F, Morosini M, Solari N, Passadore I, Nascimbene C, Novo M, et al. Foxp3 Expressing CD4+ CD25+ and CD8+CD28- T Regulatory Cells in the Peripheral Blood of Patients With Lung Cancer and Pleural Mesothelioma. Hum Immunol (2006) 67:1-12. doi: 10.1016/j.humimm.2005.11.005

15. Gershon RK, Kondo K. Cell Interactions in the Induction of Tolerance: The Role of Thymic Lymphocytes. Immunology (1970) 18:723-37.

16. Bezie S, Meistermann D, Boucault L, Kilens S, Zoppi J, Autrusseau E, et al. Ex Vivo Expanded Human Non-Cytotoxic CD8(+)CD45RC(low/-) Tregs Efficiently Delay Skin Graft Rejection and GVHD in Humanized Mice. Front Immunol (2017) 8:2014. doi: 10.3389/fimmu.2017.02014

17. Zemmour D, Zilionis R, Kiner E, Klein AM, Mathis D, Benoist C. Single-Cell Gene Expression Reveals a Landscape of Regulatory T Cell Phenotypes Shaped by the TCR. Nat Immunol (2018) 19:291-301. doi: 10.1038/s41590-018-0051-0

18. Agle K, Vincent BG, Piper C, Belle L, Zhou V, Shlomchik W, et al. Bim Regulates the Survival and Suppressive Capability of CD8 + FOXP3 +
Regulatory T Cells During Murine GVHD. Blood (2018) 132:435-47. doi: 10.1182/blood-2017-09-807156

19. Nishio J, Baba M, Atarashi K, Tanoue T, Negishi H, Yanai H, et al. Requirement of Full TCR Repertoire for Regulatory T Cells to Maintain Intestinal Homeostasis. P Natl Acad Sci U S A (2015) 112:12770-5. doi: 10.1073/pnas.1516617112

20. Fohse L, Suffner J, Suhre K, Wahl B, Lindner C, Lee CW, et al. High TCR Diversity Ensures Optimal Function and Homeostasis of Foxp3+ Regulatory T Cells. Eur J Immunol (2011) 41:3101-13. doi: 10.1002/eji.201141986

21. Heinrichs J, Li J, Nguyen H, Wu Y, Bastian D, Daethanasanmak A, et al. CD8+ Tregs Promote GVHD Prevention and Overcome the Impaired GVL Effect Mediated by CD4+ Tregs in Mice. ONCOIMMUNOLOGY (2016) 5: e1146842. doi: 10.1080/2162402X.2016.1146842

22. Iamsawat S, Daenthanasanmak A, Voss JH, Nguyen H, Bastian D, Liu C, et al. Stabilization of Foxp3 by Targeting JAK2 Enhances Efficacy of CD8 Induced Regulatory T Cells in the Prevention of Graft-Versus-Host Disease. J Immunol (Baltimore Md 1950) (2018) 201:2812-23. doi: 10.4049/ jimmunol.1800793

23. Iamsawat S, Tian L, Daenthanasanmak A, Wu Y, Nguyen HD, Bastian D, et al. Vitamin C Stabilizes CD8+ Itregs and Enhances Their Therapeutic Potential in Controlling Murine GVHD and Leukemia Relapse. Blood Adv (2019) 3:4187-201. doi: 10.1182/bloodadvances.2019000531

24. Machicote A, Belén S, Baz P, Billordo LA, Fainboim L. Human CD8+HLADR+ Regulatory T Cells, Similarly to Classical CD4+Foxp3+ Cells, Suppress Immune Responses via PD-1/PD-L1 Axis. Front Immunol (2018) 9:2788. doi: 10.3389/fimmu.2018.02788

25. Beres AJ, Haribhai D, Chadwick AC, Gonyo PJ, Williams CB, Drobyski WR. CD8+ Foxp3+ Regulatory T Cells are Induced During Graft-Versus-Host Disease and Mitigate Disease Severity. J Immunol (Baltimore Md 1950) (2012) 189:464-74. doi: 10.4049/jimmunol.1200886

26. Sawamukai N, Satake A, Schmidt AM, Lamborn IT, Ojha P, Tanaka Y, et al. Cell-Autonomous Role of Tgf $\beta$ and IL-2 Receptors in CD4+ and CD8+ Inducible Regulatory T-Cell Generation During GVHD. Blood (2012) 119:5575-83. doi: 10.1182/blood-2011-07-367987

27. Beres A, Haribhai D, Tessler-Verville C, Gonyo P, Hessner M, Williams C, et al. Induction of a Novel Population of CD8+ Foxp3+ Regulatory T Cells During Graft Versus Host Disease. Blood (2011) 118:821. doi: 10.1182/ blood.V118.21.821.821

28. Robb RJ, Lineburg KE, Kuns RD, Wilson YA, Raffelt NC, Olver SD, et al Identification and Expansion of Highly Suppressive CD8+FoxP3+ Regulatory T Cells After Experimental Allogeneic Bone Marrow Transplantation. Blood (2012) 119:5898-908. doi: 10.1182/blood-2011-12396119

29. Avivi I, Stroopinsky D, Rowe JM, Katz T. A Subset of CD8+ T Cells Acquiring Selective Suppressive Properties may Play a Role in GvHD Management. Transpl Immunol (2013) 28:57-61. doi: 10.1016/j.trim. 2012.11.006

30. Zheng J, Liu Y, Qin G, Chan P, Mao H, Lam K, et al. Efficient Induction and Expansion of Human Alloantigen-Specific CD8 Regulatory T Cells From Naive Precursors by CD40-Activated B Cells. J Immunol (2009) 183:374250. doi: 10.4049/jimmunol.0901329

31. Fleissner D, Hansen W, Geffers R, Buer J, Westendorf AM. Local Induction of Immunosuppressive CD8+ T Cells in the Gut-Associated Lymphoid Tissues. PLoS One (2010) 5:e15373. doi: 10.1371/journal.pone.0015373

32. Zhang P, Tey S, Koyama M, Kuns RD, Olver SD, Lineburg KE, et al. Induced Regulatory T Cells Promote Tolerance When Stabilized by Rapamycin and IL-2In Vivo. J Immunol (Baltimore Md 1950) (2013) 191:5291-303. doi: 10.4049/jimmunol.1301181

33. Lerret NM, Houlihan JL, Kheradmand T, Pothoven KL, Zhang ZJ, Luo X Donor-Specific CD8+Foxp3+ T Cells Protect Skin Allografts and Facilitate Induction of Conventional CD4+Foxp3+ Regulatory T Cells. Am J Transplant (2012) 12:2335-47. doi: 10.1111/j.1600-6143.2012.04120.x

34. Zheng J, Liu Y, Liu Y, Liu M, Xiang Z, Lam KT, et al. Human CD8+ Regulatory T Cells Inhibit GVHD and Preserve General Immunity in Humanized Mice. Sci Transl Med (2013) 5:168r-9r. doi: 10.1126/ scitranslmed.3004943

35. Suzuki M, Jagger AL, Konya C, Shimojima Y, Pryshchep S, Goronzy JJ, et al. CD8+CD45RA+CCR7+FOXP3+ T Cells With Immunosuppressive 
Properties: A Novel Subset Of Inducible Human Regulatory T Cells. J Immunol (2012) 189:2118-30. doi: 10.4049/jimmunol.1200122

36. Sofi MH, Heinrichs J, Dany M, Nguyen H, Dai M, Bastian D, et al. Ceramide Synthesis Regulates T Cell Activity and GVHD Development. JCI Insight (2017) 2:e91701. doi: 10.1172/jci.insight.91701

37. Yu P, Bamford RN, Waldmann TA. IL-15-Dependent CD8+ CD122+ T Cells Ameliorate Experimental Autoimmune Encephalomyelitis by Modulating IL-17 Production by CD4+ T Cells. Eur J Immunol (2014) 44:3330-41. doi: 10.1002/eji.201444675

38. Visentainer JE, Lieber SR, Persoli LB, Vigorito AC, Aranha FJ, de Brito EK, et al. Serum Cytokine Levels and Acute Graft-Versus-Host Disease After HLA-Identical Hematopoietic Stem Cell Transplantation. Exp Hematol (2003) 31:1044-50. doi: 10.1016/j.exphem.2003.08.005

39. Horwitz DA, Pan S, Ou J, Wang J, Chen M, Gray JD, et al. Therapeutic Polyclonal Human CD8+ CD25+ Fox3+ TNFR2+ PD-L1+ Regulatory Cells Induced Ex-Vivo. Clin Immunol (2013) 149:450-63. doi: 10.1016/j.clim. 2013.08.007

40. Liu Y, Lan Q, Lu L, Chen M, Xia Z, Ma J, et al. Phenotypic and Functional Characteristic of a Newly Identified CD8+Foxp3-CD103+ Regulatory T Cells. J Mol Cell Biol (2014) 6:81-92. doi: 10.1093/jmcb/mjt026

41. Zhong H, Liu Y, Xu Z, Liang P, Yang H, Zhang X, et al. TGF- $\beta$-Induced CD8 +CD103+ Regulatory T Cells Show Potent Therapeutic Effect on Chronic Graft-Versus-Host Disease Lupus by Suppressing B Cells. Front Immunol (2018) 9:35. doi: 10.3389/fimmu.2018.00035

42. Uss E, Rowshani AT, Hooibrink B, Lardy NM, van Lier RA, Ten BI. CD103 is a Marker for Alloantigen-Induced Regulatory CD8+ T Cells. J Immunol (2006) 177:2775-83. doi: 10.4049/jimmunol.177.5.2775

43. Dickinson AM, Norden J, Li S, Hromadnikova I, Schmid C, Schmetzer H, et al. Graft-Versus-Leukemia Effect Following Hematopoietic Stem Cell Transplantation for Leukemia. Front Immunol (2017) 8:496. doi: 10.3389/ fimmu.2017.00496

44. Mohr A, Malhotra R, Mayer G, Gorochov G, Miyara M. Human FOXP3 ${ }^{+} \mathrm{T}$ Regulatory Cell Heterogeneity. Clin Trans Immunol (2018) 7:e1005. doi: $10.1002 /$ cti2.1005

45. Feuerer M, Hill JA, Mathis D, Benoist C. Foxp3+ Regulatory T Cells: Differentiation, Specification, Subphenotypes. Nat Immunol (2009) 10:689-95. doi: 10.1038/ni.1760

46. Wang D, Yuan R, Feng Y, El-Asady R, Farber DL, Gress RE, et al. Regulation of CD103 Expression by CD8+ T Cells Responding to Renal Allografts. J Immunol (2004) 172:214-21. doi: 10.4049/jimmunol.172.1.214

47. Lu L, Yu Y, Li G, Pu L, Zhang F, Zheng S, et al. CD8(+)CD103(+) Regulatory T Cells in Spontaneous Tolerance of Liver Allografts. Int Immunopharmacol (2009) 9:546-8. doi: 10.1016/j.intimp.2009.01.021

48. Liu J, Chen D, Nie GD, Dai Z. CD8+CD122+ T-Cells: A Newly Emerging Regulator With Central Memory Cell Phenotypes. Front Immunol (2015) 6:494. doi: 10.3389/fimmu.2015.00494

49. Cosmi L, Liotta F, Lazzeri E, Francalanci M, Angeli R, Mazzinghi B, et al. Human CD8+CD25+ Thymocytes Share Phenotypic and Functional Features With CD4+CD25+ Regulatory Thymocytes. Blood (2003) 102:4107-14. doi: 10.1182/blood-2003-04-1320

50. Zheng SG, Wang JH, Koss MN, Quismorio FJ, Gray JD, Horwitz DA. CD4+ and CD8+ Regulatory T Cells Generated Ex Vivo With IL-2 and TGF-Beta Suppress a Stimulatory Graft-Versus-Host Disease With a Lupus-Like Syndrome. J Immunol (2004) 172:1531-9. doi: 10.4049/jimmunol.172.3.1531

51. Hu Y, Luo Y, Zheng W, Tan Y, Huang H. Foxp3+ Regulatory T Cell Subsets Are Induced In Alloreactive Microenvironment and Associated With Chronic GraftVersus-Host Disease Severity After Allogeneic Hematopoietic Stem Cell Transplantation. Blood (2013) 122:3307. doi: 10.1182/blood.V122.21.3307.3307

52. Gunnlaugsdottir B, Maggadottir SM, Skaftadottir I, Ludviksson BR. TheEx Vivo Induction of Human CD103+ CD25hi Foxp3+ CD4+ and CD8+ Tregs is IL-2 and TGF- $\beta 1$ Dependent. Scand J Immunol (2013) 77:125-34. doi: $10.1111 /$ sji.12009

53. Zhang X, Ouyang X, Xu Z, Chen J, Huang Q, Liu Y, et al. CD8+CD103+ Itregs Inhibit Chronic Graft-Versus-Host Disease With Lupus Nephritis by the Increased Expression of CD39. Mol Ther (2019) 27:1963-73. doi: 10.1016/j.ymthe.2019.07.014

54. Janikashvili N, Trad M, Gautheron A, Samson M, Lamarthée B, Bonnefoy F, et al. Human Monocyte-Derived Suppressor Cells Control Graft-Versus-
Host Disease by Inducing Regulatory Forkhead Box Protein 3-Positive CD8 + T Lymphocytes. J Allergy Clin Immun (2015) 135:1614-24. doi: 10.1016/ j.jaci.2014.12.1868

55. Xystrakis E, Dejean AS, Bernard I, Druet P, Liblau R, Gonzalez-Dunia D, et al. Identification of a Novel Natural Regulatory CD8 T-Cell Subset and Analysis of its Mechanism of Regulation. Blood (2004) 104:3294-301. doi: 10.1182/blood-2004-03-1214

56. Simone R, Zicca A, Saverino D. The Frequency of Regulatory CD3+ CD8+ CD28- CD25+ T Lymphocytes in Human Peripheral Blood Increases With Age. J Leukocyte Biol (2008) 84:1454-61. doi: 10.1189/jlb.0907627

57. Vuddamalay Y, van Meerwijk JPM. CD28- and CD28lowCD8+ Regulatory T Cells: Of Mice and Men. Front Immunol (2017) 8:31. doi: 10.3389/fimmu. 2017.00031

58. Fenoglio D, Ferrera F, Fravega M, Balestra P, Battaglia F, Proietti M, et al. Advancements on Phenotypic and Functional Characterization of nonAntigen-Specific CD8+CD28- Regulatory T Cells. Hum Immunol (2008) 69:745-50. doi: 10.1016/j.humimm.2008.08.282

59. Parodi A, Battaglia F, Kalli F, Ferrera F, Conteduca G, Tardito S, et al. CD39 is Highly Involved in Mediating the Suppression Activity of TumorInfiltrating CD8+ T Regulatory Lymphocytes. Cancer Immunol Immunother (2013) 62:851-62. doi: 10.1007/s00262-013-1392-Z

60. Rifa'I M, Kawamoto Y, Nakashima I, Suzuki H. Essential Roles of CD8 $+\mathrm{CD} 122+$ Regulatory T Cells in the Maintenance of T Cell Homeostasis. J Exp Med (2004) 200:1123-34. doi: 10.1084/jem.20040395

61. Dai H, Wan N, Zhang S, Moore Y, Wan F, Dai Z. Cutting Edge: Programmed Death-1 Defines CD8+CD122+ T Cells as Regulatory Versus Memory T Cells. J Immunol (2010) 185:803-7. doi: 10.4049/jimmunol.1000661

62. Shi Z, Rifa IM, Lee YH, Shiku H, Isobe KI, Suzuki H. Importance of CD80/ CD86-CD28 Interactions in the Recognition of Target Cells by CD8+CD122+ Regulatory T Cells. Immunology (2008) 124:121-8. doi: 10.1111/j.1365-2567.2007.02747.x

63. Liu H, Qiu F, Wang Y, Zeng Q, Liu C, Chen Y, et al. CD8+CD122+PD-1+ Tregs Synergize With Costimulatory Blockade of CD40/CD154, But Not B7/ CD28, to Prolong Murine Allograft Survival. Front Immunol (2019) 10:306. doi: 10.3389/fimmu.2019.00306

64. Shi Z, Okuno Y, Rifa'I M, Endharti AT, Akane K, Isobe K, et al. Human CD8 + CXCR3+ T Cells Have the Same Function as Murine CD8+ CD122+ Treg. Eur J Immunol (2009) 39:2106-19. doi: 10.1002/eji.200939314

65. Dai Z, Zhang S, Xie Q, Wu S, Su J, Li S, et al. Natural CD8+CD122+ T Cells Are More Potent in Suppression of Allograft Rejection Than CD4+CD25+ Regulatory T Cells. Am J Transplant (2014) 14:39-48. doi: 10.1111/ajt.12515

66. Qiu F, Liu H, Liang C, Nie GD, Dai Z. A New Immunosuppressive Molecule Emodin Induces Both CD4+FoxP3+ and CD8+CD122+ Regulatory T Cells and Suppresses Murine Allograft Rejection. Front Immunol (2017) 8:1519. doi: $10.3389 /$ fimmu.2017.01519

67. Stanzani M, Martins SLR, Saliba RM, John LSS, Bryan S, Couriel D, et al. CD25 Expression on Donor CD4+ or CD8+ T Cells is Associated With an Increased Risk for Graft-Versus-Host Disease After HLA-Identical Stem Cell Transplantation in Humans. Blood (2004) 103:1140-6. doi: 10.1182/blood-2003-06-2085

68. Mutis T, Aarts-Riemens T, Verdonck LF. The Association of CD25 Expression on Donor CD8+ and CD4+ T Cells With Graft-Versus-Host Disease After Donor Lymphocyte Infusions. Haematologica (2005) 90:138995. doi: $10.3324 / \% 25 \mathrm{x}$

69. Georgiev P, Charbonnier LM, Chatila TA. Regulatory T Cells: The Many Faces of Foxp3. J Clin Immunol (2019) 39:623-40. doi: 10.1007/s10875-019-00684-7

70. Suffia I, Reckling SK, Salay G, Belkaid Y. A Role for CD103 in the Retention of $\mathrm{CD} 4+\mathrm{CD} 25+$ Treg and Control of Leishmania Major Infection. J Immunol (2005) 174:5444-55. doi: 10.4049/jimmunol.174.9.5444

71. El-Asady R, Yuan R, Liu K, Wang D, Gress RE, Lucas PJ, et al. TGF- $\beta$ Dependent CD103 Expression by CD8+ T Cells Promotes Selective Destruction of the Host Intestinal Epithelium During Graft-Versus-Host Disease. J Exp Med (2005) 201:1647-57. doi: 10.1084/jem.20041044

72. Moesta AK, Li X, Smyth MJ. Targeting CD39 in Cancer. Nat Rev Immunol (2020) 20:739-55. doi: 10.1038/s41577-020-0376-4

73. Filaci G, Fravega M, Negrini S, Procopio F, Fenoglio D, Rizzi M, et al. Nonantigen Specific CD8+ T Suppressor Lymphocytes Originate From CD8 +CD28- T Cells and Inhibit Both T-Cell Proliferation and CTL Function. Hum Immunol (2004) 65:142-56. doi: 10.1016/j.humimm.2003.12.001 
74. Vuddamalay Y, Attia M, Vicente R, Pomié C, Enault G, Leobon B, et al. Mouse and Human CD8+ CD28low Regulatory T Lymphocytes Differentiate in the Thymus. Immunology (2016) 148:187-96. doi: 10.1111/imm.12600

75. Heiler S, Lötscher J, Kreuzaler M, Rolink J, Rolink A. Prophylactic and Therapeutic Effects of Interleukin-2 (IL-2)/Anti-IL-2 Complexes in Systemic Lupus Erythematosus-Like Chronic Graft-Versus-Host Disease. Front Immunol (2018) 9:656. doi: 10.3389/fimmu.2018.00656

76. Meguri Y, Ohashi K, Inamoto Y, Iyama S, Ohwada C, Murata M, et al. Sustained Immunogenic and Clinical Effects of Low-Dose Interleukin-2 Therapy With an Intermittent Maintenance Method for Refractory Chronic Graft-Versus-Host Disease: Results of Phase1/2a LDIL2-01 Study. Biol Blood Marrow $\operatorname{Tr}$ (2020) 26:S175. doi: 10.1016/j.bbmt.2019.12.732

77. Sun X, Xiao Y, Zeng Z, Shi Y, Tang B, Long H, et al. All-Trans Retinoic Acid Induces CD4+CD25+FOXP3+ Regulatory $\mathrm{T}$ Cells by Increasing FOXP3 Demethylation in Systemic Sclerosis CD4+ T Cells. J Immunol Res (2018) 2018:8658156-8658157. doi: 10.1155/2018/8658156

78. Ma J, Liu Y, Li Y, Gu J, Liu J, Tang J, et al. Differential Role of All-Trans Retinoic Acid in Promoting the Development of CD4+ and CD8+ Regulatory T Cells. J Leukocyte Biol (2014) 95:275-83. doi: 10.1189/jlb.0513297

79. Chen X, Das R, Komorowski R, Beres A, Hessner MJ, Mihara M, et al. Blockade of Interleukin-6 Signaling Augments Regulatory T-Cell Reconstitution and Attenuates the Severity of Graft-Versus-Host Disease. Blood (2009) 114:891-900. doi: 10.1182/blood-2009-01-197178

80. Belle L, Agle K, Zhou V, Yin-Yuan C, Komorowski R, Eastwood D, et al. Blockade of Interleukin-27 Signaling Reduces GVHD in Mice by Augmenting Treg Reconstitution and Stabilizing Foxp3 Expression. Blood (2016) 128:2068-82. doi: 10.1182/blood-2016-02-698241

81. Gaignage M, Marillier RG, Cochez PM, Dumoutier L, Uyttenhove C, Coutelier J, et al. The TLR7 Ligand R848 Prevents Mouse Graft- Versus -Host Disease and Cooperates With Anti-Interleukin-27 Antibody for Maximal Protection and Regulatory T-Cell Upregulation. Haematologica (2019) 104:392-402. doi: 10.3324/haematol.2018.195628

82. Le HT, Keslar K, Nguyen QT, Blazar BR, Hamilton BK, Min B. Interleukin-27 Enforces Regulatory T Cell Functions to Prevent Graft-Versus-Host Disease. Front Immunol (2020) 11:181. doi: 10.3389/fimmu.2020.00181

83. Picarda E, Bézie S, Boucault L, Autrusseau E, Kilens S, Meistermann D, et al. Transient Antibody Targeting of CD45RC Induces Transplant Tolerance and Potent Antigen-Specific Regulatory T Cells. Am Soc Clin Invest (2017) 2 (3):e90088. doi: 10.1172/jci.insight.90088

84. Vlad G, Stokes MB, Liu Z, Chang C, Sondermeijer H, Vasilescu ER, et al. Suppression of Xenogeneic Graft-Versus-Host Disease by Treatment With Immunoglobulin-Like Transcript 3-Fc. Hum Immunol (2009) 70:663-9. doi: 10.1016/j.humimm.2009.06.001

85. Li LMP, Patsoukis NP, Nellore AM, Boussiotis VAMP. Inhibition of Cdk2 Inactivates EZH2 and Induces Epigenetic Regulation of Fopx3 Leading to the Generation of CD8+ Treg and Protection From GvHD. Biol Blood Marrow $\operatorname{Tr}$ (2014) 20:S53. doi: 10.1016/j.bbmt.2013.12.055

86. Betts BC, Bastian D, Iamsawat S, Nguyen H, Heinrichs JL, Wu Y, et al. Targeting JAK2 Reduces GVHD and Xenograft Rejection Through Regulation of T Cell Differentiation. Proc Natl Acad Sci U S A (2018) 115:1582-7. doi: 10.1073/pnas.1712452115

87. Kasahara H, Okamoto S, Sekiya T, Yoshimura A. Vitamin C Stabilizes Foxp3 Expression in Induced Treg Cells By Targeted DNA Demethylation and Prevents Murine Model of Acute Graft Versus Host Disease. Blood (2017) 130:70. doi: 10.1182/blood.V130.Suppl_1.70.70

88. Chakraborty S, Panda AK, Bose S, Roy D, Kajal K, Guha D, et al. Transcriptional Regulation of FOXP3 Requires Integrated Activation of Both Promoter and CNS Regions in Tumor-Induced CD8(+) Treg Cells. Sci Rep (2017) 7:1628. doi: 10.1038/s41598-017-01788-z

89. Chougnet CA, Tripathi P, Lages CS, Raynor J, Sholl A, Fink P, et al. A Major Role for Bim in Regulatory T Cell Homeostasis. J Immunol (2010) 186:15663. doi: 10.4049/jimmunol.1001505

90. Wang X, Szymczak-Workman AL, Gravano DM, Workman CJ, Green DR, Vignali DAA. Preferential Control of Induced Regulatory T Cell Homeostasis via a Bim/Bcl-2 Axis. Cell Death Dis (2012) 3:e270. doi: $10.1038 /$ cddis. 2012.9

91. Zhang C, Liu J, Zhong JF, Zhang X. Engineering CAR-T Cells. Biomark Res (2017) 5:22. doi: 10.1186/s40364-017-0102-y
92. Pehlivan KC, Duncan BB, Lee DW. CAR-T Cell Therapy for Acute Lymphoblastic Leukemia: Transforming the Treatment of Relapsed and Refractory Disease. Curr Hematol Malig R (2018) 13:396-406. doi: 10.1007/ s11899-018-0470-x

93. Mansourabadi AH, Mohamed Khosroshahi L, Noorbakhsh F, Amirzargar A. Cell Therapy in Transplantation: A Comprehensive Review of the Current Applications of Cell Therapy in Transplant Patients With the Focus on Tregs, CAR Tregs, and Mesenchymal Stem Cells. Int Immunopharmacol (2021) 97:107669. doi: 10.1016/j.intimp.2021.107669

94. Bezie S, Charreau B, Vimond N, Lasselin J, Gerard N, Nerriere-Daguin V, et al. Human CD8+ Tregs Expressing a MHC-Specific CAR Display Enhanced Suppression of Human Skin Rejection and GVHD in NSG Mice. Blood Adv (2019) 3:3522-38. doi: 10.1182/bloodadvances.2019000411

95. Seng A, Krausz KL, Pei D, Koestler DC, Fischer RT, Yankee TM, et al. Coexpression of FOXP3 and a Helios Isoform Enhances the Effectiveness of Human Engineered Regulatory T Cells. Blood Adv (2020) 4:1325-39. doi: 10.1182/bloodadvances.2019000965

96. Rouas R, Merimi M, Najar M, El Zein N, Fayyad Kazan M, Berehab M, et al. Human CD8+ CD25+ CD127low Regulatory T Cells: microRNA Signature and Impact on TGF- $\beta$ and IL-10 Expression. J Cell Physiol (2019) 234:17459-72. doi: 10.1002/jcp.28367

97. Jebbawi F, Fayyad-Kazan H, Merimi M, Lewalle P, Verougstraete JC, Leo O, et al. A microRNA Profile of Human CD8(+) Regulatory T Cells and Characterization of the Effects of microRNAs on Treg Cell-Associated Genes. J Transl Med (2014) 12:218. doi: 10.1186/s12967-014-0218-x

98. Traverso I, Fenoglio D, Negrini S, Parodi A, Battaglia F, Kalli F, et al. Cyclophosphamide Inhibits the Generation and Function of CD8+ Regulatory T Cells. Hum Immunol (2012) 73:207-13. doi: 10.1016/j.humimm.2011.12.020

99. Wang L, Ni M, Hückelhoven-Krauss A, Sellner L, Hoffmann J, Neuber B, et al. Modulation of B Cells and Homing Marker on NK Cells Through Extracorporeal Photopheresis in Patients With Steroid-Refractory/Resistant Graft-Vs.-Host Disease Without Hampering Anti-Viral/Anti-Leukemic Effects. Front Immunol (2018) 9:2207. doi: 10.3389/fimmu.2018.02207

100. Engela AU, Baan CC, Dor FJMF, Weimar W, Hoogduijn MJ. On the Interactions Between Mesenchymal Stem Cells and Regulatory T Cells for Immunomodulation in Transplantation. Front Immunol (2012) 3:126. doi: 10.3389/fimmu.2012.00126

101. Weng JY, Du X, Geng SX, Peng YW, Wang Z, Lu ZS, et al. Mesenchymal Stem Cell as Salvage Treatment for Refractory Chronic GVHD. Bone Marrow Transpl (2010) 45:1732-40. doi: 10.1038/bmt.2010.195

102. Qiuli LHZX. Human Mesenchymal Stromal Cells Enhance the Immunomodulatory Function of CD8+CD28- Regulatory T Cells. Cell Mol Immunol (2015) 12:708-18. doi: 10.1038/cmi.2014.118

103. Chen J, Zhou Y, Chen S, Liu M, Guo W, Wang Q, et al. Lkb1 in Dendritic Cells Restricts CD8+Foxp3+regulatory T Cells Expansion In Vivo. Exp Cell Res (2019) 384:111650. doi: 10.1016/j.yexcr.2019.111650

104. Lee JG, Jaeger KE, Seki Y, Wei LY, Cunha C, Vuchkovska A, et al. Human CD36(hi) Monocytes Induce Foxp3(+) CD25(+) T Cells With Regulatory Functions From CD4 and CD8 Subsets. Immunology (2021) 163(3):293-309. doi: $10.1111 /$ imm. 13316

Conflict of Interest: The authors declare that the research was conducted in the absence of any commercial or financial relationships that could be construed as a potential conflict of interest.

Publisher's Note: All claims expressed in this article are solely those of the authors and do not necessarily represent those of their affiliated organizations, or those of the publisher, the editors and the reviewers. Any product that may be evaluated in this article, or claim that may be made by its manufacturer, is not guaranteed or endorsed by the publisher.

Copyright (c) 2021 Wang, Hong, Wang, Wang, Du, Gao, Yang and Zhang. This is an open-access article distributed under the terms of the Creative Commons Attribution License (CC BY). The use, distribution or reproduction in other forums is permitted, provided the original author(s) and the copyright owner(s) are credited and that the original publication in this journal is cited, in accordance with accepted academic practice. No use, distribution or reproduction is permitted which does not comply with these terms. 